\title{
Job satisfaction and employee performance - Determination by discipline, organization culture, and competence
}

\author{
Agus Rony Katily ${ }^{1}$ A; Zainal Ilmi ${ }^{2}$ A; Siti Amalia 3 A \\ A University of Mulawarman, Indonesia
}

Received: December 28, 2020 | Revised: February 17, 2021 | Accepted: February 28, 2021

JEL Classification: J28, J54, M12, C36

DOI: $10.33445 /$ sds.2021.11.1.5

\begin{abstract}
The existence of HRM requires strategic planning. Regarding HRM development, companies must focus on the sustainability of their systems and practices. The focus of this paper is based on job satisfaction and employee performance, so we limit the determinants of discipline, culture, and competence to that. The method requires in-depth exploration through surveys or direct interviews with respondents with 59 employees at PT Trimanunggal Nugraha Samarinda. Then, the data were processed from a questionnaire instrument and seven hypotheses tested with multivariate analysis or SEM-PLS. There are two stages of presentation, namely assessing the measurement model and the structural model. In the first structure, we find that discipline, organizational culture, and competence have a positive-significant effect on job satisfaction. For the second structure, only one hypothesis can be accepted with the explanation that competence has a positive-significant effect on employee performance. Meanwhile, discipline and job satisfaction have a positive-insignificant effect on employee performance, but organizational culture actually has a negative impact on employee performance because the results are negative-insignificant. The contribution and added value of this empirical study can be used as benchmarks for the right decision-makers such as the main director, special divisions, and planning boards.
\end{abstract}

Key words: company employees, HRM, multivariate, Samarinda.

\section{Introduction}

The process framework in achieving organizational goals which are implemented in employee performance is an important factor because employee performance is a measure of the extent to which the employee's ability to carry out their duties and functions is in accordance with what is given by the organization. The low implementation of the quality of human resources proves that employee performance is still low. This is inseparable from members of the organization, one of which is employees. Companies that have poor employee performance are generally caused by employee performance that does not experience an increase in employee performance. The low performance of employees is also shown by the system for achieving the vision and mission of the company (Maria et al., 2020; Purwadi et al., 2020; Darma et al., 2020).

Improving employee performance requires several things such as high competence, adequate discipline, good discipline, and an organizational culture that supports employees to be able to improve their performance (Zainurossalamia, 2020). The skills acquired through technical training can create innovation and creativity in determining one's performance.

Employees who already have good

\footnotetext{
${ }^{1}$ Corresponding author: Faculty of Economics and Business, Department of Management, Master Student, e-mail: agusronykatily@gmail.com

${ }^{2}$ Faculty of Economics and Business, Department of Management, Dr (Assoc. Prof), e-mail: zainal.ilmi@feb.unmul.ac.id, ORCID: 0000-0002-3176-3954

${ }^{3}$ Faculty of Economics and Business, Department of Economics, Dr (Assoc. Prof), e-mail: siti.amalia@feb.unmul.ac.id, ORCID: 0000-0002-9054-4567
} 
competence, the organization will retain employees to continue working by providing incentives, allowances, etc. according to their competence, with appropriate reciprocity between the organization and the employees who work, then the employees will commit to the organization she works. Employees who are highly committed to their organization can support the achievement of organizational goals and organizational progress. Competence is a basic characteristic of a person that enables them to perform optimally in their work. Competence is also a deep and inherent part of a person's personality with predictable behavior in a variety of job situations and tasks. Several things contained in performance are also connected to the achievement of work programs (Wijayanti et al., 2020; Faradila et al., 2020).

The competence of employees at PT Trimanunggal Nugraha Samarinda in carrying out their duties and responsibilities can be said that they are still not optimal. It can be seen through the execution of the planned program that they have not been able to be optimally realized so that the achievement of performance is still not fulfilled according to the plan that has been made. Another thing that hinders the optimization of task completion by employees so that it has an impact in the form of decision-making obstacles (Maria et al., 2020). The cause of the emergence of this problem is the organization's internal human resources that are not running as they should be due to a decrease in job satisfaction which is directly related to a decrease in employee performance at PT Trimanunggal Nugraha in Samarinda.

Employee performance is a record of employee achievement against certain job requirements that can be measured and assessed. Werther \& Davis (2008) adds that employee performance can also be defined as all work results in job functions and specific activities in a certain period. Optimizing the performance of PT Trimanunggal Nugraha Samarinda employees is a form of employee sincerity in working in the company. Employees, as one of the implementing elements in the company environment, are obliged to provide optimal performance. Bujang et al. (2020) has reviewed the success and performance of a person's employees in a field of work determined by discipline, organizational culture, competence, and satisfaction in working in the field they are engaged in.

Employee performance can be said to be still not optimal. Another thing that becomes an obstacle to optimizing employee performance is the dissemination of information on new programs and evaluation of programs that have been implemented has been delayed so that it has an impact in the form of decision-making obstacles (Pusriadi \& Darma, 2020). The cause of the emergence of this problem is the internal human resources of the organization that are not running as they should be, not being felt maximally so that employees have an impact on employee satisfaction and performance.

This paper refers to the phenomena and problems that have been described, so we need to see the determination of discipline, organizational culture, and competence on job satisfaction and employee performance. The study limitation only covers employees at PT Trimanunggal Nugraha Samarinda with an export presentation.

\section{Material and methods}

Measurements. This paper is included in the category of explanative research that seeks to explain the causal relationship between theoretical support and facts (e.g. IImi et al., 2020; lkbal et al., 2020). The variables only cover two groups, namely the dependent variable which is indicated by job satisfaction and employee performance, then there are

independent variables divided into discipline, organizational culture, and competence.

Classification of variables. In order for the study to focus on the initial objectives while avoiding misinterpretation, we need to describe the operational definition of each variable adopted and developed by Ratnasari et al. $(2019,2020)$ as follows: 
1. Employee performance is a process in which employees of PT Trimanunggal Nugraha Samarinda experience to progress through certain levels of achievement. Limitation regarding indicators that shape employee performance consists of work quality, work quantity, and time efficiency.

2. Job satisfaction is defined as the feeling of pleasure of employees due to the perception that their work fulfills or enables the fulfillment of important work values of employees. Indicators to measure job satisfaction include the job itself, supervisors (supervise), coworkers, promotions, and workers' employees of PT Trimanunggal Nugraha.

3. Discipline is an orderly condition, in which the employees of PT Trimanunggal Nugraha in Samarinda are subject to existing regulations. With the assessment indicators work discipline is divided into three categories (timeliness, good use of office equipment, and responsibility).

4. Organizational culture is a shared meaning system adopted by employees that differentiates an organization from other organizations. This system of shared meaning is a set of key characteristics that are held in high esteem by organizations. Organizational culture is measured by several instruments that combine innovation, employee attention, team orientation, and employee stability.

5. Competence is the ability for a task, skills, attitudes, and appreciation needed by employees to support success, so it is measured by indicators through thinking skills, conceptual flexibility, originality, and skill.

Data set. Data collection involved all employees of PT Trimanunggal Nugraha Samarinda with a survey. The sampling technique is aimed at saturated sampling, because it is included in the non-probability sampling category (Ratnasari \& Lestari, 2020). Considering the relatively small population, we need to survey by the census, where the entire population is sampled. In the end, to explore the satisfaction and performance of PT
Trimanunggal Nugraha Samarinda employees limited it to 59 informants.

Analysis tools. Eliyana et al. (2019) confirm that data analysis is a process of simplifying data into a form that is easier to read and interpret. From this session, statistics are often used. One of the main functions of statistics is to simplify the enormous amounts of research data into information that is simpler and easier to understand. The method to answer the research objectives is the Structural Equation ModelPartial Least Square (SEM-PLS).

A complete SEM modeling basically consists of a measurement model and a structural model. The measurement model is intended to confirm a dimension or factor based on empirical indicators (Herman et al., 2020; Jogiyanto, 2011). Hypothesis testing is carried out by a series of stages from a multivariate analysis run through the SmartPLS program to assess the outer model and inner model.

Hypothesis mapping. Based on a review of relevant theories and studies related to this paper, we propose seven hypotheses as follows:

1. Hypothesis 1 - There is a positivesignificant influence between discipline on job satisfaction.

2. Hypothesis 2 - There is a positivesignificant influence between organizational culture on job satisfaction.

3. Hypothesis 3 - There is a positivesignificant influence between competence on job satisfaction.

4. Hypothesis 4 - There is a positivesignificant influence between discipline on employee performance.

5. Hypothesis 5 - There is a positivesignificant influence between organizational culture on employee performance.

6. Hypothesis 6 - There is a positivesignificant influence between competence on employee performance.7. Hypothesis 7 - There is a positive-significant influence between job satisfaction on employee performance.

\section{Results and discussion}

Calculation using PLS. The determination of job satisfaction and employee performance is organizational culture, and competence at PT 
Trimanunggal Nugraha Samarinda. It can be factor value for each indicator in it, a new seen through the analysis of the relationship research model can be obtained (see Figure 1). between these variables. Based on the loading

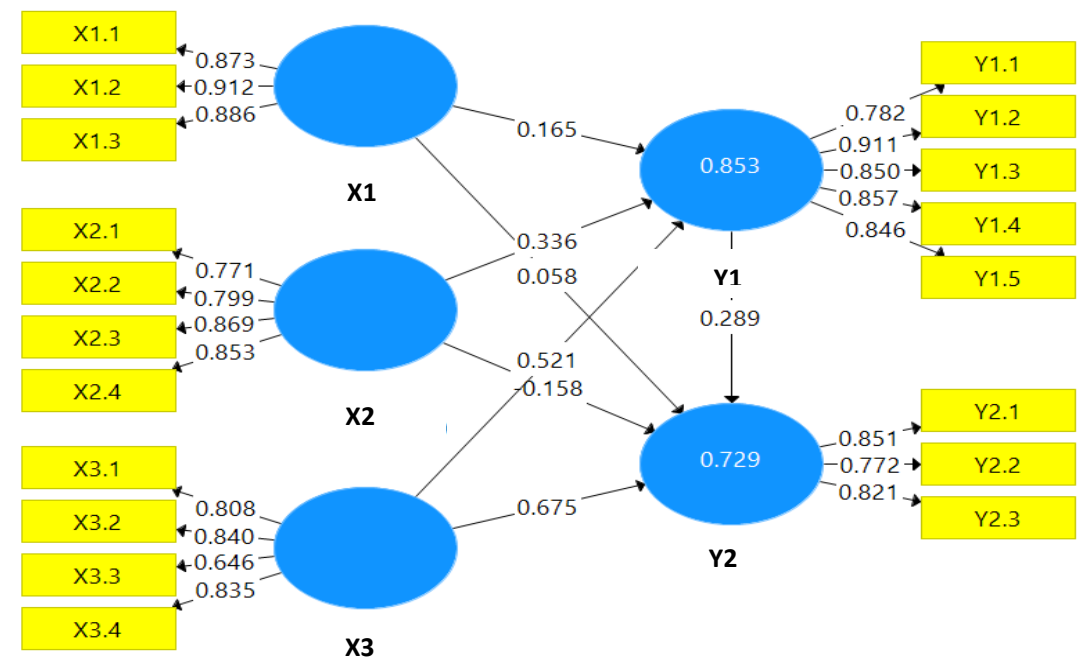

Figure 1 - Structural estimation

Source: Author's processing.

The determination of job satisfaction and employee performance is determined by factors including work discipline, organizational culture, and competence at PT Trimanunggal Nugraha Samarinda. It can be seen through the analysis of the relationship between these variables. Based on the loading factor value for each indicator in it, a new research model can be obtained (see Figure 1).

As a continuation, Jogiyanto (2011) considers that the research model loading factor $>0.70$ is highly recommended. However, if the loading factor is between $0.50-0.60$, a model can still be tolerated as long as it is still in the development stage. From this explanation, that all loading factors are $>0.50$, so the research can be continued to analyze the measurement model or the outer model and the inner model.
Outer model: discriminant validity and composite reliability. First, the interpretation of Average Variance Extracted (AVE) and its square root is summarized in Table 1. Variables can be said to be valid discriminant, as reflected in the AVE acquisition. For constructs with good validity, AVE is required to be $>0.50$. We can conclude that the acquisition of AVE $>0.50$ means that the instrument variables are classified as valid discriminants. Another way to determine the level of discriminant validity of a variable can also be obtained from the square root of AVE (VAVE) by comparing a construct with the correlation value between other constructs. If the result is higher than the correlation between other constructs, it can be concluded that the instrument has met the criteria.

Table 1 -Predictions based on AVE

\begin{tabular}{|l|c|c|c|c|}
\hline \multicolumn{1}{|c|}{ Variables } & AVE & Decisions & VAVE & Decisions \\
\hline Discipline & 0.793 & Accepted & 0.890 & Accepted \\
\hline Organizational culture & 0.679 & Accepted & 0.824 & Accepted \\
\hline Competence & 0.618 & Accepted & 0.786 & Accepted \\
\hline Job satisfaction & 0.723 & Accepted & 0.850 & Accepted \\
\hline Employee performance & 0.665 & Accepted & 0.815 & Accepted \\
\hline
\end{tabular}

Source: Author's processing. 
As for the AVE connected to the square root, the results for all variables are $>0.50$. This indicates that the discipline instrument is 0.890 , organizational culture is 0.824 , competency is

Table 2 -Expectations of Composite reliability

\begin{tabular}{|l|l|l|}
\hline \multicolumn{1}{|c|}{ Variables } & Ratio & Decisions \\
\hline Discipline & 0.920 & Accepted \\
\hline Organizational culture & 0.894 & Accepted \\
\hline Competence & 0.865 & Accepted \\
\hline Job satisfaction & 0.929 & Accepted \\
\hline Employee performance & 0.856 & Accepted \\
\hline
\end{tabular}

Source: Author's processing.

Second, the achievement of composite reliability to determine the reliability of all constructs in the information presented in Table 2. A reliable construct must meet the criteria or value of the composite reliability value $>0.70$. The statistical output shows all constructs for each of the variables (discipline, organizational culture, competence, job satisfaction, and employee performance), namely 0.920, 0.894, 0.865, 0.929, and 0.856 . The value of composite reliability has met the classification and is considered reliable.

Inner model: GoF and partial test. First, the examination of the Goodness of Fit (GoF) is
0.786 , job satisfaction is 0.850 , and performance is 0.815 . In conclusion, all variables for this model are valid. supported by the R-square value (R2), with the explanation in Table 3 which indicates that the model interprets the phenomenon of job satisfaction explained by discipline, organizational culture, and competence of $84.50 \%$. After that, the error term in the model reaches $15.50 \%$ which is a variation beyond that. The phenomenon of performance variation has been discussed by discipline, organizational culture, competence, and job satisfaction reaching $70.90 \%$, of which $29.10 \%$ are variables outside the provisions.

Table 3 -Projections for the GoF

\begin{tabular}{|l|l|l|}
\hline \multicolumn{1}{|c|}{ Variables } & Ratio & Decisions \\
\hline Job satisfaction & 0.845 & Adequate \\
\hline Employee performance & 0.709 & Adequate \\
\hline
\end{tabular}

Source: Author's processing.

The meaning of the positive relationship between the independent variables is that they are able to encourage an increase in job satisfaction and employee performance. If the

Table 4-Confirmation of the hypothesis

\begin{tabular}{|l|l|l|l|l|l|}
\hline \multicolumn{1}{|c|}{ Hypothesis } & \multicolumn{1}{c|}{ Path } & \multicolumn{1}{c|}{ OSE } & \multicolumn{1}{|c|}{ T-statistics } & \multicolumn{1}{c|}{ P-values } & \multicolumn{1}{c|}{ Remarks } \\
\hline H1 & D --> JS & 0.165 & 2.526 & 0.012 & Supported \\
\hline H2 & OC --> JS & 0.336 & 4.394 & 0.000 & Supported \\
\hline H3 & C --> JS & 0.521 & 5.426 & 0.000 & Supported \\
\hline H4 & D --> EP & 0.058 & 0.570 & 0.569 & Not supported \\
\hline H5 & OC --> EP & -0.156 & 1.236 & 0.217 & Not supported \\
\hline H6 & C --> EP & 0.675 & 4.512 & 0.000 & Supported \\
\hline H7 & JS --> EP & 0.289 & 1.747 & 0.081 & Not supported \\
\hline
\end{tabular}

Source: Author's processing, Note: OSE (Original Sample Estimate).

relationship is negative, it indicates that the independent variables have not been optimal in increasing employee satisfaction and performance. 
Second, the SmartPLS program produces a partial test (t-test) on each path. The result, the test is described in Table 4. That way, it can be selected about the effect and significance level of each variable. If the T-statistic $>1.96$ concludes that the independent variable has a significant effect on the dependent variable and vice versa, if the T-statistic decision is $<1.96$, it does not have a significant effect. Our description is summarized as follows:

1. Discipline has a positive-significant effect on job satisfaction. It can also be seen that discipline has a significant effect on job satisfaction, so it is in line with the previous hypothesis design.

2. Organizational culture has a positivesignificant effect on job satisfaction, so it is in line with the previous hypothesis design.

3. Competence has a positive-significant effect on job satisfaction, so it is in line with the previous hypothesis design.

4. Discipline has a positive-insignificant effect on employee performance, it is contrary to the previous hypothesis design.

5. Organizational culture has a negativeinsignificant effect on employee performance, so it is contrary to the previous hypothesis design.

6. Competence has a positive-significant effect on employee performance, so it is in line with the previous hypothesis design.

7. Job satisfaction has a positive-insignificant effect on employee performance, it is contrary to the previous hypothesis design.

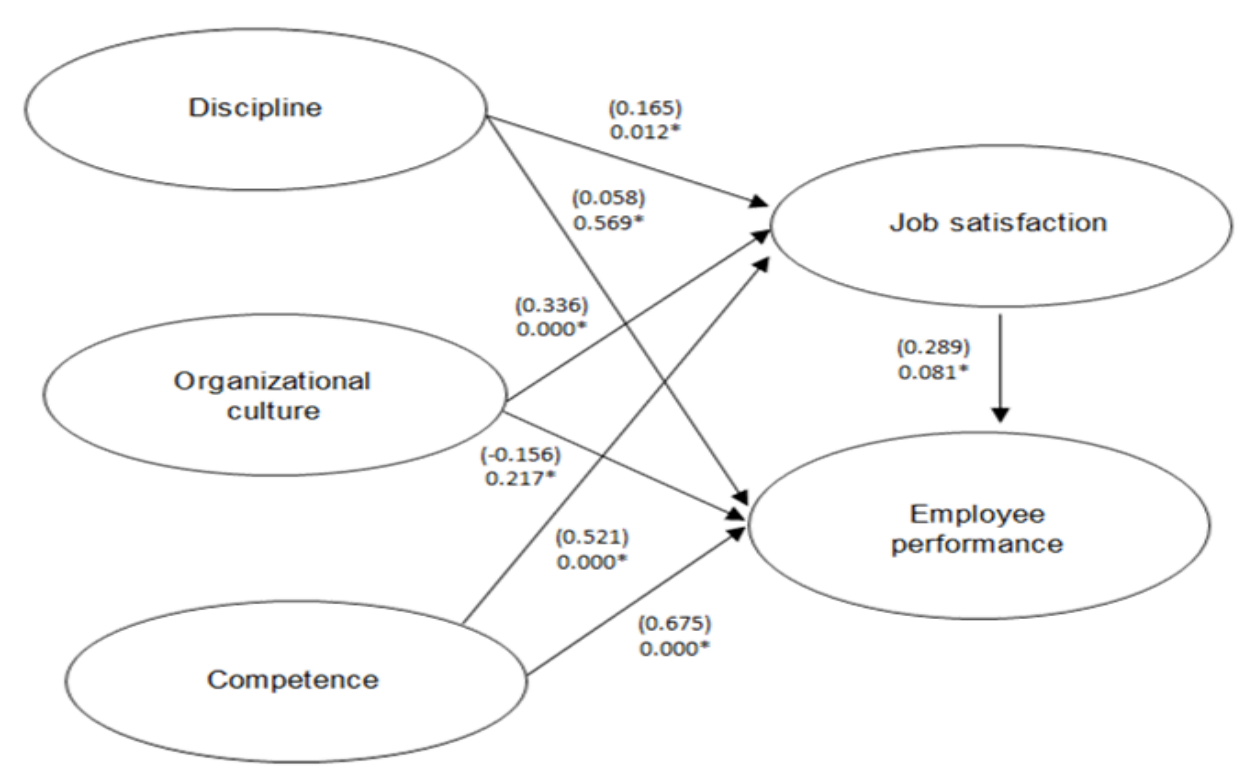

Figure 2 - Partial coefficients and probabilities

Source: Author's processing, Note: *Level of probability 0.05 (5\%).

Third, based on the testing of each hypothesis, it is developed with illustrations from the results of statistical estimation which show that four hypotheses are supported and three hypotheses are apparently not supported. The assumptions for all constructs used are valid and reliable so that the structural model built to test the hypothesis shows the accuracy of the model which is able to explain its achievement.

Relevance of findings. Attitudes or actions are complementary affective, cognitive, and behavioral reactions. Meanwhile, the attitudes that are most often actualized are things that are effective. Attitude or behavioral aspects of employees towards various studies designed to measure factors that influence and hinder individual work are often interpreted as facets of job satisfaction. The relevance of studies conducted by Muslichah \& Asrori (2018), Alonderiene \& Majauskaite (2016), and Saleem (2015) reveals that discipline has a positive and significant effect on job satisfaction. 
According to Mathis et al. (2017), every member of the organization has the same opportunity, for example for promotion, the basis used for promotion is an ability, skills, interests, discipline, performance without discrimination. It should be noted, the discipline has an important relationship with employee performance because discipline is one aspect of the process of employee performance. Employee performance and discipline usually develop independently to some extent. Discipline is also an important component of employee performance. Meyer (2015) believes that work discipline is considered an important part of employee performance. Daud et al. (2013) in a study clarified that discipline has a significant effect on employee performance, while Widjaja \& Supriyatna (2020) concluded that discipline has no significant effect on employee performance.

Robbins \& Judge (2015) believe that organizational culture is part of important core competency in an organization. In general, individuals, groups, and organizations operate under their culture even though they are almost intangible. Organizational culture is a link between the organization or place of work and employee satisfaction. Qazi et al. (2017), Belias \& Koustelios (2014), Ahamed \& Mahmood (2015), and Alvi et al. (2014) highlighted the role of organizational culture which has a positive and significant impact on job satisfaction.

Organizational culture can affect productivity, employee performance, employee commitment, employee confidence, and ethical behavior of the employee towards the organization itself. Organizational culture and discipline style certainly have a systematic impact on employee organizational commitment, job satisfaction, and employee performance. Kim \& Chang (2019) and Srisathan et al. (2020) observed that organizational culture has a significant effect on employee performance, while Magsi et al. (2018) concluded that organizational culture has an insignificant influence on employee performance.

Through competencies and adjustments between employees' internal competencies, the implementation of these adjustments can be encouraged through intensive training and education. With this program, it is hoped that they can add experience, insight, expertise, and abilities so that it will increase job satisfaction. Tang et al. (2019), Weigelt et al. (2019), and Chiniara \& Bentein (2016) concluded that competence has a significant effect on employee job satisfaction. On the one hand, Adam \& Kamase (2019) give special points for employee job satisfaction which is insignificantly affected by competence.

Employees who have a high opportunity to improve their career will stimulate their discipline to work better. Organizations that have a systematic model in the competence of their employees will have a commitment to a good organization. Research conducted by Nasution (2017), Rulandari (2017), and Apenteng (2012) states that competence has a positive and significant impact on employee performance. The difference in previous findings was revealed by Adam \& Kamase (2019) that competence has no significant effect on employee performance.

Job satisfaction is supported by employees' perceptions of how well the job is (job feasibility) because it provides things that are considered important. The six components in job satisfaction can be measured by the job description index (the job itself is related to responsibility, interest, and growth, the quality of supervision related to technical assistance and social support, relationships with colleagues related to social harmony and respect, opportunities promotions related to opportunities for further development, and payments related to adequate wages and perceptions of fairness (Luthans et al., 2010). Rolfö et al. (2018) and Arifin (2015) consider that job satisfaction has no significant effect on employee performance. On the other hand, a different point of view was concluded by Sabuhari et al. (2020) which emphasized that job satisfaction has a significant effect on employee performance. 


\section{Conclusions}

Referring to our observations regarding investigations of job satisfaction and employee performance represented by discipline, organizational culture, and competence can provide several important points, where structure-1 in the first, second, and third hypotheses supports the statement that discipline, organizational culture, and competence positive-significant effect on job satisfaction at PT Trimanunggal Nugraha Samarinda. For structure-2, it only supports the sixth hypothesis (competence has a positivesignificant effect on employee performance), while the fifth hypothesis is not supported because the organizational culture has a negative-insignificant effect on employee performance. The fourth and seventh hypotheses are also not supported by this finding, because discipline and job satisfaction have a positive-insignificant effect on the performance of the employees of PT Trimanunggal Nugraha Samarinda.

Discipline should run according to the expectations of PT Trimanunggal Nugraha Samarinda by implementing an integrated discipline system, especially a system that is able to make employees go to the office on time. The organizational culture that has been running, can be re-evaluated by building a culture based on innovation and creativity, in order to optimize job satisfaction and employee performance of PT Trimanunggal Nugraha Samarinda. Based on the results of the search, we emphasize the variable of organizational culture, employees should also be obedient in terms of time because it can have an impact on the effectiveness of time to complete work so that they have a good organizational culture. These steps are expected to enhance the culture of the company.

So far, the increased competency that has been implemented has been able to reflect their job satisfaction, so it is worth maintaining if employees always have the ability to create originality. In addition, they always work according to applicable operational standards with high initiative, so that work can be completed effectively and efficiently. At the employee competency level, they should revitalize their skills and knowledge. By knowing the drawbacks of these two things, you can find the right solution through internal and external training held by the company. These steps are of course a concrete effort to improve individual and team competence.

Additional implications also need to be improved, in the form of communication between leaders and employees or vice versa involving employees to leaders, so that performance achievement can be achieved according to company needs. In terms of organizational culture, collected through the creation of a conducive atmosphere, so that they are able to provide optimal performance in achieving performance. The next improvement information is the improvement of competence through employee behavior because it is needed in order to achieve maximum performance. Individual awareness is needed to form conducive competencies in a corporate environment.

Research development related to strategic HRM, especially those related to job satisfaction and employee performance, should be thoroughly highlighted. To that end, the expansion for future studies can be pursued with more detailed observations for organizational progress and variance.

\section{References}

Adam, F., \& Kamase, J. (2019). The effect competence and motivation to satisfaction and performance. International Journal of Scientific and Technology Research, 8(3), 132-140.

Ahamed, M., \& Mahmood, R. (2015). Impact of Organizational Culture on Job Satisfaction: A
Study on Banglalion Communication Ltd, Bangladesh. European Journal of Business and Management, 7(10), 160-174.

Alonderiene, R., \& Majauskaite, M. (2016). Leadership style and job satisfaction in higher education institutions. International Journal of 
Educational Management, 30(1), 140-164.

DOI: 10.1108/IJEM-08-2014-0106

Alvi, H. A., Hanif, M., Adil, M. S., Ahmed, R. R., \& Vveinhardt, J. (2014). Impact of Organizational Culture on Organizational Commitment and Job Satisfaction. European Journal of Business and Management, 6(27), 30-39.

Arifin, H. M. (2015). The Influence of Competence, Motivation, and Organisational Culture to High School Teacher Job Satisfaction and Performance. International Education Studies, 8(1), 38-45. DOI: 10.5539/ies.v8n1p38

Belias, D., \& Koustelios, A. (2014). Organizational Culture and Job Satisfaction: A Review. International Review of Management and Marketing, 4(2), 132-149.

Bujang, R., Kasuma, J., Isnin, N., Neging, P., Hassan, A. N., Darma, D. C., \& Kuleh, Y. (2020). Relationship Between Client Satisfaction, Service Quality and Client Perception Towards the Effectiveness of Client Consultation Services. International Journal of Psychosocial Rehabilitation, 24(03), 5648-5656. DOI: 10.37200/IJPR/V24I3/PR2021164

Chiniara, M., \& Bentein, K. (2016). Linking servant leadership to individual performance: Differentiating the mediating role of autonomy, competence and relatedness need satisfaction. The Leadership Quarterly, 27(1), 124-141. DOI: 10.1016/j.leaqua.2015.08.004

Darma, D. C., Purwadi, P., Sundari, I., Hakim, Y. P., \& Pusriadi, T. (2020). Job Characteristics, Individual Characteristics, Affective Commitments and Employee Performance. Research and Review: Human Resource and Labour Management, 10(1), 7-18. DOI: 10.5281/zenodo.3719117

Daud, N. M., Idris, A. S., Manaf, N. A., \& Mudzaffar, F. A. (2013). Relationship between sports involvement and students' performance in Malaysian University. International Journal of Undergraduates Studies, 2(3), 32-39.

Eliyana, A., Ma'arif, S., \& Muzakki. (2019). Job satisfaction and organizational commitment effect in the transformational leadership towards employee performance. European Research on Management and Business Economics, 25(3), 144-150. DOI: 10.1016/j.iedeen.2019.05.001

Faradila, N., Heksarini, A., \& Darma, D. C. (2020). Antecedents That Affect Job Satisfaction and Employee Performance. Saudi Journal of Business and Management Studies, 5(6), 293302. DOI: $10.36348 / \mathrm{sjbms.2020.v05i06.001}$

Herman, L. D., Setiyaningrum, A., \& Ferdinand, A. T. (2020). Techno-entrepreneurial relationship marketing to ignite the SMEs marketing performance in Indonesia. Quality - Access to Success, 19(167), 98-106.

Ikbal, M., Irwansyah, I., Paminto, A., Ulfah, Y., \& Darma, D. C. (2020). Financial intelligence: Financial statement fraud in Indonesia. Journal of Intelligence Studies in Business, 10(3), 80-95. DOI: $10.37380 /$ jisib.v10i3.640

Ilmi, Z., Darma, D. C., \& Wijayanti, T. C. (2020). Can servqual mediate from the store atmosphere and customer satisfaction? Management Theory and Studies for Rural Business and Infrastructure Development, 42(3), 359-368. DOI: 10.15544/mts.2020.36

Jogiyanto, J. (2011). Partial Least Square (PLS), Alternatif Structural Equation Modeling (SEM) Dalam Penelitian Bisnis (in English: Partial Least Square (PLS), Alternative Structural Equation Modeling (SEM) in Business Research). Yogyakarta: Andi.

Kim, T., \& Chang, J. (2019). Organizational culture and performance: a macro-level longitudinal study. Leadership \& Organization Development Journal, 40(1), 65-84. DOI: 10.1108/LODJ-082018-0291

Luthans, F., Avey, J. B., Avolio, B. J., \& Peterson, S. J. (2010). The development and resulting performance impact of positive psychological capital. Human Resource Development Quarterly, 21(1), 41-67. DOI: 10.1002/hrdq.20034

Magsi, H. B., Ong, T. S., Ho, J. A., \& Hassan, A. F. (2018). Organizational Culture and Environmental Performance. Sustainability, 10(8), 2690. DOI: 10.3390/su10082690

Maria, S., Darma, D. C., \& Setyawan, H. (2020). PLS-SEM to Predict the Relationship between Procedural Justice, Organizational Commitment, OCB, and Job Satisfaction. Journal of Wellbeing Management and Applied 
Psychology, 3(3), 01-13. DOI:

10.13106/jwmap.2020.Vol3.no3.1

Maria, S., Permadi Hakim, Y., \& Darma, D. C. (2020). Perceptions of Service Quality and Corporate Image Against Satisfaction and Customer Loyalty. KnE Social Sciences, 4(3), 925. DOI: $10.18502 / \mathrm{kss} . v 4 i 3.6371$

Mathis, R., Jackson, J., Valentine, S., \& Meglich P. (2017). Human Resources Management, 15th ed. Ohio: Cenage Learning.

Meyer, J. P. (2015). Organizational Commitment. Wiley Encyclopedia of Management, 1-3. DOI: 10.1002/9781118785317.weom050052

Muslichah, M., \& Asrori, S. (2018). The Effect of Transformational Leadership Style on Job Satisfaction with Trust-In-Leader as Intervening Variable. Journal of Innovation in Business and Economics, 2(2),61-70. DOI: 10.22219/jibe.v2i02.6580

Purwadi, P., Darma, D. C., Febrianti, W., \& Mirwansyah, D. (2020). Exploration of Leadership, Organizational Culture, Job Satisfaction, and Employee Performance. Technium Social Sciences Journal, 6(1), 116130. DOI: $10.47577 /$ tssj.v6i1.242

Pusriadi, T., \& Darma, D. C. (2020). Pengaruh talent management dan employee engagement terhadap employee capabilities: Studi pada karyawan PT Bintang Wahana Tata (in English: The effect of talent management and employee engagement on employee capabilities: A study on employees of PT Bintang Wahana Tata). Jurnal Riset Entrepreneurship, 3(1), 54-61. DOI: 10.30587/jre.v3i1.1317

Qazi, S., Miralam, M. S., \& Bhalla, P. (2017). Organizational culture and job satisfaction: A study of organized retail sector. Journal of Business and Retail Management Research, 12(1), 215-224. DOI: 10.24052/JBRMR/V12IS01/OCAJSASOORS

Ratnasari, S. L., Sutjahjo, G., \& Adam, A. (2019). Employees' Performance: Organizational Culture And Leadership Style Through Job Satisfaction. Humanities \& Social Sciences Reviews, 7(5), 597-608. DOI: 10.18510/hssr.2019.7569

Ratnasari, S. L., Rahmawati, R., Haryani, D. S.,
Tanjung, R., \& Basuki, B. (2020). Workplace Bullying Causing Negative Employee Behaviors: A Case from Indonesian Banking Sector. International Journal of Innovation, Creativity and Change, 10(11), 441-458.

Ratnasari, S. L., and Lestari, L. (2020). Effect of Leadership Style, Workload, Job Insecurity on Turnover Intention. International Journal of Innovation, Creativity and Change, 11(12), 299-313.

Robbins, S. P., \& Judge, T. A. (2015). Organizational Behavior, 16th ed. New Jersey: Pearson Prentice Hall.

Rolfö, L., Eklund, J., \& Jahncke, H. (2018). Perceptions of performance and satisfaction after relocation to an activity-based office. Ergonomics, 61(5), 644-657. DOI: 10.1080/00140139.2017.1398844

Sabuhari, R., Sudiro, A., Irawanto, D. W., Rahayu, M. (2020). The effects of human resource flexibility, employee competency, organizational culture adaptation and job satisfaction on employee performance. Management Science Letters, 10(8), 17751786. DOI: 10.5267/j.msl.2020.1.001

Saleem, H. (2015). The Impact of Leadership Styles on Job Satisfaction and Mediating Role of Perceived Organizational Politics. Procedia Social and Behavioral Sciences, 172, 563-569. DOI: 10.1016/j.sbspro.2015.01.403

Srisathan, W. A., Ketkaew, C., \& Naruetharadhol, P. (2020). The intervention of organizational sustainability in the effect of organizational culture on open innovation performance: A case of thai and chinese SMEs. Cogent Business \& Management, 7(1), 1717408. DOI: 10.1080/23311975.2020.1717408

Tang, C., Tian, B., Zhang, X., Zhang, K., Xiao, X., Simoni, J. M., \& Wang, H. (2019). The influence of cultural competence of nurses on patient satisfaction and the mediating effect of patient trust. Journal of Advanced Nursing, 75(4), 749759. DOI: 10.1111/jan.13854

Weigelt, O., Syrek, C. J., Schmitt, A., \& Urbach, T. (2019). Finding peace of mind when there still is so much left undone-A diary study on how job stress, competence need satisfaction, and proactive work behavior contribute to work- 
related rumination during the weekend. Journal of Occupational Health Psychology, 24(3), 373-386. DOI: 10.1037/ocp0000117

Werther, W. B., \& Davis, K. (2008). Human Resources \& Personnel Management, 5th ed. New York: Mc-Graw Hill Inc.

Widjaja, R., \& Supriyatna, E. (2020). Pengaruh Strategi Pengembangan SDM Terhadap Kinerja Karyawan. Jurnal Manajemen Bisnis dan Kewirausahaan, 4(2), 63-68. DOI: 10.24912/jmbk.v4i2.7523

Wijayanti, T. C., Setini, M., Darma, D. C., Purwadi,
P., \& Alka, P. R. (2020). Connectivity Continuous Improvement Program and Employee Performance. International Review of Management and Marketing, 10(1), 54-62. DOI: 10.32479/irmm.9161

Zainurossalamia, S., Darma, D. C., Kasuma, J., Ratnasari, S. L., \& Tasenţe, T. (2020). Apparatus Performance as Mediation of Creativity and Innovation Towards the Successful Application of e-Kelurahan. European Journal of Human Resource Management Studies, 4(2), 108-126. DOI: 10.5281/zenodo.3546289 